\title{
Future directions in prevention and treatment of children obesity and eating disorders
}

\author{
Rita Tanas ${ }^{1 *}$, Guido Caggese ${ }^{2}$, Simonetta Marucci ${ }^{3}$ \\ From 71st Congress of the Italian Society of Pediatrics. Joint National Meeting SIP, SIMGePeD, Study Group \\ on Pediatric Ultrasound, SUP Study Group on Hypertension \\ Rome, Italy. 4-6 June 2015
}

The childhood obesity epidemic has promoted many healthcare programs focused on nutritional education in order to teach correct nutrition and to promote early diagnosis and care of overweight/obese children including offering them a correct food supply.

For almost 20 years, however, scientific literature has pointed out that eating disorders (ED), which typically onset during adolescence, are increasing, and that dieting (restrictive behaviors, adopted today by many adults and adolescents, mostly managed without the support of a professional format, to match the ideal of thinness proposed by the media and being or feeling overweight are likely to be the most avoidable facilitating factors [1-4].

Body stigma, shared by those with obesity and ED [5] and based on the attribution of a strong personal responsibility in the onset of these diseases, has been shown to increase stress, blood pressure, cortisol, oxidative stress, C-reactive protein and worse glycemic control, while decreasing motivation for physical activity (PA) encouraging a sedentary lifestyle. Stigma also increases psychosocial issues, such as depression, bodyimage distortion, loss of oral control and affects motivation and effectiveness of treatments.

Primary care staff are increasingly asked to promote parents awareness on their children being overweight although this has been recognized as a trigger for the onset of an ED [6], but at the same time they are not provided with adequate means to run a truly effective therapeutic program (strategies to promote change, such as the patient-centered motivational interview) and the suffering related to family and professional weight-derision.

Children are then pushed to see themselves as fat, to dislike themselves and go on a diet, focusing dangerously

\footnotetext{
* Correspondence: tanas.rita@tin.it

${ }^{1}$ UO Pediatria, Azienda Ospedaliero Universitaria, Ferrara, Italy

Full list of author information is available at the end of the article on food, body and weight and with the result of being bullied in many life contexts such as home, school, medical services. All this leads to dysfunctional eating patterns, loss of control and increased BMI. It has been reported that obesity is the strongest predictive factor to the onset of an ED [7]. The pervasive and universal body and weight-stigma enhances restrictive behavior and creates a vicious circle that leads to a real ED epidemic among young adults [8]. It's time to think about obesity prevention and treatment in a different way (Tables 1 and 2), getting to know EDs [8,9] and using tools that do not favor them, protecting children against weightstigma, especially ones coming from parents, educators and health workers [10].

\section{Authors' details}

${ }^{1}$ UO Pediatria, Azienda Ospedaliero Universitaria, Ferrara, Italy. ${ }^{2}$ Formazione Professionale, Azienda Ospedaliero Universitaria, Ferrara, Italy. ${ }^{3}$ Centro per il trattamento dei Disturbi del Comportamento Alimentare, Todi, Perugia, Italy.

Published: 30 September 2015

\section{References}

1. Field AE, Austin SB, Taylor CB, Malspeis S, Rosner B, Rockett HR, et al: Relation between dieting and weight change among preadolescents and adolescents. Pediatrics 2003, 112(4):900-906.

2. Neumark-Sztainer D, Wall M, Story M, Standish AR: Dieting and unhealthy weight control behaviors during adolescence: associations with 10-year changes in body mass index. J Adolesc Health 2012, 50(1):80-86.

3. Finistrella V, Manco M, Corciulo N, Sances B, Di Pietro M, Di Gregorio R, et al: Eating Disorders and Psychopathological Traits in Obese Preadolescents and Adolescents. J Am Coll Nutr 2015, 9(2):1-8.

4. Patton GC, Selzer R, Coffey C, Carlin JB, Wolfe R: Onset of adolescent eating disorders: population based cohort study over 3 years. BMJ 1990, 318(7186):765-768.

5. Puhl R, Suh Y: Stigma and eating and weight disorders. Curr Psychiatry Rep 2015, 17(3):552.

6. Allen $\mathrm{KL}$, Byrne SM, Forbes D, Oddy WH: Risk factors for full- and partialsyndrome early adolescent eating disorders: a population-based pregnancy cohort study. J Am Acad Child Adolesc Psychiatry 2009, 48(8):800-809. 
Table 1. Multiple strategies for a comprehensive systemic-oriented approach to childhood obesity and ED [11-14]

\begin{tabular}{ll}
\hline Actions & Setting \\
\hline $\begin{array}{l}\text { Regulating the commerce of energy-dense nutrition-poor foods, cosmetics and cosmetic surgery for minors to their } \\
\text { health needs }\end{array}$ & Governments, Schools \\
\hline $\begin{array}{l}\text { Controling sophisticated marketing strategies of unhealthy food, sedentary activities and weight loss products to which } \\
\text { children are often exposed }\end{array}$ & Governments, Media \\
\hline Restricting the use of very underweight fashion models (BMl<18) and digitally-altered photographs of models & Governments, Media \\
\hline Protecting people from weight discrimination and bullism, both in workplaces and clinical settings & Governments, Media \\
\hline Educating people eating healthy food and physical activities and marketing & Families, School educators \\
\hline Offering healthy food and promote physical activities during school-time and after-school & Schools, Community \\
\hline Training on prevention and early diagnosis of eating disorders and weight-related diseases & Schools, Sports coach, \\
\hline Promoting attention and prevention to professional anti-fat bias in school and clinical practice & Healthcare \\
\hline Handling with weight-stigmatized or bullied children & Schools, Sports coach, \\
\hline Training on patient-centered motivational counselling & Schools, Healthcare \\
\hline Empowering children to cope with media-based and culturally inappropriate messages and promoting acceptance of & Schools \\
the diversity of beauty and attractiveness, enhancing inner qualities versus appearance and expression of discomfort. & Healthcare \\
\hline
\end{tabular}

Table 2. Themes for Professional Training about Childhood Obesity for Primary Care (PC) and Multiprofessional Teams (Pediatricians, hospital, nutritionists, psychologists)

\begin{tabular}{lll}
\hline Number & Items & Healthcare \\
\hline $\mathbf{1}$ & Epidemiology and Etiology update & PC \\
\hline $\mathbf{2}$ & Diagnosis criteria: use of BMl z score according to the WHO growth charts & $\begin{array}{l}\text { PC and } \\
\text { Team }\end{array}$ \\
\hline $\mathbf{4}$ & $\begin{array}{l}\text { Principles of Motivational Interviewing and its application in Primary Care } \\
\text { motivation to behaviors' change }\end{array}$ & PC and \\
\hline $\mathbf{5}$ & Developing awareness on empathy and derision towards people with obesity. & Team \\
\hline $\mathbf{6}$ & Handling with weight and body-stigma promoted by families, school educators and health professionals & PC and \\
\hline $\mathbf{7}$ & Proactive assessment of the outcome of care and its communication to families
\end{tabular}

7. Sim LA, Lebow J, Billings M: Eating disorders in adolescents with a history of obesity. Pediatrics 2013, 132(4):e1026-e1030.

8. Griffiths S, Mond JM, Murray SB, Touyz S: The prevalence and adverse associations of stigmatization in people with eating disorders. Int J Eat Disord 2004, doi: 10.1002/eat.22353.

9. De Luca G, Tanas R, Ruggiero F, Chiavetta S, Sicoli C, De Luca F, et al: La pediatria di famiglia ed i disturbi del comportamento alimentare nelle prime fasi dell'adolescenza. Rivista Italiana di Medicina dell'Adolescenza 2013, 11():5-9.

10. Marucci S: Buone pratiche di cura nei disturbi del comportamento alimentare: verso le linee guida. Rivista Italiana di Medicina dell'Adolescenza 2013, 11():35-40

11. Dietz WH, Baur LA, Hall K, Puhl RM, Taveras EM, Uauy R, et al: Management of obesity: improvement of health-care training and systems for prevention and care. Lancet 2015, 385(9986):2521-2533.

12. Golan M, Hagay N, Tamir S: The effect of "in favor of myself": preventive program to enhance positive self and body image among adolescents. PloS One 2013, 8(11):e78223.

13. Lobstein T, Jackson-Leach R, Moodie ML, Hall KD, Gortmaker SL, Swinburn BA, et al: Child and adolescent obesity: part of a bigger picture. Lancet 2015, 385(9986):2510-2520.

14. Puhl RM, Neumark-Sztainer D, Austin SB, Luedicke J, King KM: Setting policy priorities to address eating disorders and weight stigma: views from the field of eating disorders and the US general public. BMC Public Health 2014, 14:524.

doi:10.1186/1824-7288-41-S2-A72

Cite this article as: Tanas et al:: Future directions in prevention and

treatment of children obesity and eating disorders. Italian Journal of Pediatrics 2015 41(Suppl 2):A72

\section{Submit your next manuscript to BioMed Central and take full advantage of:}

- Convenient online submission

- Thorough peer review

- No space constraints or color figure charges

- Immediate publication on acceptance

- Inclusion in PubMed, CAS, Scopus and Google Scholar

- Research which is freely available for redistribution 